УДК 81-139.2

DOI: https://doi.org/10.17721/APULTP.2020.41.177-193

\author{
Olga O. Zlotnyk-Shagina \\ ORCID ID: 0000-0003-4367-7532
}

\title{
TEXT IN MODELING THE LANGUAGE CONSCIOUSNESS OF FOREIGN STUDENTS
}

\begin{abstract}
The article considers the text as the main tool in the process of learning the Ukrainian language for foreign students. The text helps not only in learning the foreign language, but also in learning the mentality and the formation of intercultural competence. That is why the initial postulate of the theory of linguistics in Ukraine is the focus on the study of Ukrainian culture in the process of learning the language through various media and sources of national and cultural information, for example, through the text. For this purpose, texts and tasks for them have been developed, which will later be included in the educational and methodological development intended for foreigners studying the Ukrainian language. The article presents a classification of tasks that accompany the texts by stages of their implementation and examples of such tasks for the rapid study of Ukrainian as a foreign language. The main task of a teacher of Ukrainian as a foreign language is to make the most of the material of the textbook for the development of grammar and language skills and abilities of students, because they need to encourage them to express themselves and prepare for natural communication. The purpose of training always determines the choice of methods. For foreigners studying the Ukrainian language, the motivation is mainly constructive communication with Ukrainian-speakers, official correspondence in the Ukrainian language, i.e. professional activity. And in this aspect, the creative approach to working with the text is an effective solution to educational problems, which is based on the analysis of the relationship between language and speech, speech and thinking, thinking and communication. Therefore, the article presents a practical part of working with the text to learn the Ukrainian language. The textbook for learning Ukrainian as a foreign language is not only a means of teaching foreign students to read in Ukrainian, but also a great opportunity to form and develop their speaking, listening and writing skills, so in the arsenal of every teacher of Ukrainian
\end{abstract}


as a foreign language should be different texts which correspond to the cultural theme as well as the interests and abilities of students.

Keywords: text, language consciousness, study of the Ukrainian language as a foreign language, original text, adapted text, types of text tasks.

Information about the authors: Zlotnyk-Shagina Olga Oleksandrivna - PhD, associate professor; Glier Kyiv Institute of Music; assistant of the department of Ukrainian and Russian languages as Foreign Languages; Institute of philology; Taras Shevchenko National University of Kyiv.

E-mail: ozlotnik@bigmir.net

Злотник-Шагіна О.О.

ORCID ID: 0000-0003-4367-7532

\section{ТЕКСТ У МОДЕЛЮВАННІ МОВНОЇ СВІДОМОСТІ СТУДЕНТІВ-ІНОЗЕМЦІВ}

Анотація. У статті розглянуто текст як основний засіб у прочесі навчання украӥнської мови для іноземних студентів. Текст допомагає не лише у вивченні мови іншого народу, а ци у пізнанні ментальності та формуванні міжкультурної компетенції, зокрема у формуванні мовної свідомості. Саме тому, вихідним постулатом теорії лінгвокрайнознавства в Украйні є орієнтація на вивчення украӥнської культури в прочесі навчання мові через різноманітні носії та джерела начіонально-культурної інформачії, наприклад, через текст / контекст. Для цього розроблено тексти та завдання до них, які в подальшому ввійдуть у навчально-методичну розробку, призначену для іноземиів, які вивчають українську мову. У статті розглядається лінгвокраӥнознавчий аспект до вивчення тексту, подано класифікацію завдань, які супроводжують тексти, за етапами їх виконання та зразки таких завдань для швидкого вивчення української мови як іноземної. Основне завдання викладача украӥнської мови як іноземної полягає в тому, щзоб максимально використати матеріал навчального тексту для розвитку граматичних та стилістичних навичок $i$ умінь студентів, адже потрібно спонукати їх до висловлення та підготовки до природного спілкування. Для іноземиів, які вивчають украӥнську мову, переважно дає мотивацію конструктивна комунікація з украйномовними носіями, офіційне 
листування украӥнською мовою, тобто професійна діяльність, а також формування мовної свідомості та мовної компетенції. цьому аспекті творчий підхід в роботі з текстом є ефективним ріменням навчальних завдань, яке трунтується на аналізі співвідношення мови $i$ мовлення, мовлення $i$ мислення, мислення $i$ комунікації. Тому у статті подана практична частина роботи з текстом для вивчення украӥнської мови. Навчальний текст, отже, при вивченні української мови як іноземної являе собою не тільки засіб навчання іноземних студентів читання українською мовою, але $i$ можливість для формування $і$ розвитку у них навичок говоріння, аудіювання та письма, репрезентовано різноманітними текстами різної тематики для формування мовної свідомості студентівіноземиів.

Ключові слова: текст, мовна свідомість, вивчення украӥнської мови як іноземної, лінгвокраїнознавство, оригінальний текст, адаптований текст, види текстових завдань.

Інформація про автора: Злотник-Шагіна Ольга Олександрівна - кандидат філологічних наук, дочент; Київський інститут музики імені Р.М. Глісра; асистент кафедри украӥнської та російської мов як іноземних; Інститут філологї; Київський національний університет імені Тараса Шевченка.

Електронна адреса: ozlotnik@bigmir.net

Злотник-Шагина О.О.

ORCID ID: 0000-0003-4367-7532

\title{
ТЕКСТ В МОДЕЛИРОВАНИИ ЯЗЫКОВОГО СОЗНАНИЯ СТУДЕНТОВ-ИНОСТРАНЦЕВ
}

\begin{abstract}
Аннотация. В статье рассмотрен текст как основное средство в прочессе обучения украинскому языку для иностранных студентов. Текст помогает не только в изучении языка другого народа, но $и$ в познании ментальности и формировании межкультурной компетенции. Именно поэтому, исходным постулатом теории лингвострановедения в Украине является ориентация на изучение украинской культуры в процессе обучения языку через различные носители и источники национально-культурной информации, например, через текст. Для этого разработаны тексты
\end{abstract}




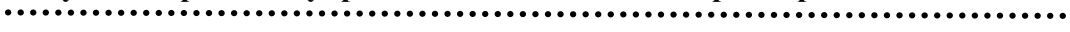

u задания к ним, которые в дальнейшем войдут в учебнометодическую разработку, предназначенную для иностранцев, изучающих украинский язык. В статье представлена классификация задач, которые сопровождают тексты, по этапам их выполнения $и$ образиы таких задач для быстрого изучения украинского языка как иностранного. Основная задача преподавателя украинского языка как иностранного заключается в том, чтобы максимально использовать материал учебного текста для развития грамматических и речевых навыков и умений студентов, ведь нужно побудить их к высказыванию и подготовки к естественному общению. Цель обучения всегда определяет выбор методов. Для иностранцев, изучающих украинский язык, в основном дает мотивацию конструктивное общение с украиноязычными, официальная переписка на украинском языке, то есть профессиональная деятельность. И в этом аспекте творческий подход в работе с текстом является эффективныл решением учебных задач, основанных на анализе соотношении языка и речи, речи и мышления, мышления $u$ коммуникации. Поэтому в статье представлена практическая часть работы с текстом для изучения украинского языка. Учебный текст при изучении украинского языка как иностранного представляет собой не только средство обучения иностранных студентов чтения на украинском языке, но и прекрасную возможность для формирования и развития у них навыков говорения, аудирования $и$ письма, поэтому в арсенале каждого преподавателя украинского языка как иностранного должны быть разнообразные тексты , которые соответствуют культурной тематике, а также интересам и способностям студентов.

Ключевые слова: текст, изучение украинского языка как иностранного, лингвострановедение, оригинальныцй текст, адаптированный текст, виды текстовых заданий.

Информация об авторе: Злотник Ольга Александровна кандидат филологических наук, доцент; Киевский институт музыки им. Р.М. Глиера; ассистент кафедры украинского и русского языка как иностранного; Институт филологии; Киевский национальнылй университет имени Тараса Шевченко.

Электронный адрес: ozlotnik@bigmir.net

Due to the socio-political events of recent years, Ukraine has attracted the attention of many countries around the world, and interest in the Ukrainian language and those who want to study it is 
constantly growing. Accordingly, the number of foreign students in Ukrainian educational institutions is increasing every year. In order to ensure a high-quality approach to the communicative foundations of learning the Ukrainian language, it is important to develop appropriate methodological developments in teaching Ukrainian as a foreign language. Obviously, this is also due to the formation of the language consciousness of foreigners, which is implemented in the "temporary search for the concept of language consciousness with the help of associations (associative field) and the influence of various linguistic cultures on mass consciousness" [11, p. 29].

A very important point in learning a foreign language is to study the historical and cultural facts of the country, as well as its elements of social reality, any manifestations of relations between native speakers. It is appropriate to speak about the language and language consciousness of A. Turkevich, who notes that language is the main feature of the nation, expresses the culture of the people who speak it, that is, the national culture. Therefore, it is necessary to teach a language as a foreign language not only as a new code, a new way of expressing thoughts, but also as a source of evidence about the culture of the people whose language a student is learning. An important prerequisite for effective language teaching is the need to quickly introduce the student to cultural processes, without which it is impossible to adequately perceive information in the language being studied [7, p. 277].

In the context of Ukrainian linguomethodics, a lot of research, scientific and methodological work was carried out within the framework of Linguo-Foreign Studies. The issue of cultural orientation of training has become particularly acute. This interest is motivated by the relevance due to the change in the approach to learning foreign languages. These objective factors, of course, led to a rethinking of the linguistic and Foreign Studies aspect in teaching Ukrainian as a foreign language.

It is common knowledge that linguocultural studies include the study of language personality, the linguistic picture of the world and language consciousness, which is associated with the works of E. Vereshchagin, V. Kostomarov, A. Taranenko, A. Vezhbitskaya, 
S. Ermolenko etc., who actively popularized the term "linguocultural studies" in the Slavic scientific space. According to R. MignardBeloruchev and O. Oberemko, this is how they translated the French term "language and civilization" (langue et civilization). It should also be noted that Linguistics has different denominations in different countries. This indicates a very wide range of issues related to the interaction of language and culture, as well as the presence of national specifics in their consideration. So in Germany it is cultural studies (kulturkunde), in the USA - language and territory (Language and area), in the UK - linguocultural studies (linguocultural studies).

We emphasize that E. Vereshchagin and V. Kostomarov considered linguocultural studies as the dominant aspect of teaching a language to foreigners, in which, in order to ensure the communicativeness of learning and to solve educational and humanistic problems, the accumulative function of the language is implemented and the addressee is acculturated, and the teaching method has a philological nature - familiarization is carried out through the mediation of the language and in the process of its study [9, p. 232]. Important here is the cognitive nature of language, which implies the knowledge of language by its communicants [11, p. 21]. For learning Ukrainian as a foreign language, this aspect is especially relevant, because it involves foreigners learning a non-native language through knowledge of its Basic Rules and norms, phraseology, verbalized cultural codes, etc.

The regional orientation of teaching the Ukrainian language as a foreign language provides not only for rapid assimilation of the language, but also for foreign students to study information about the phenomena of Ukrainian culture. Studying texts as models of language consciousness, it is important to emphasize the initial postulate of the theory of linguocultural studies in Ukraine, which is aimed at orienting the study of Ukrainian culture in the process of teaching the language through various native speakers and sources of national and cultural information.

The text as one of the sources of national and cultural information is considered in our article, the purpose of which is to 
develop and analyze sample texts for learning Ukrainian as a foreign language, as well as to systematize the tasks developed for each of these texts. It should be noted that we paid attention not only to the structure of the text, its subject matter and style characteristics when using them in the learning process of foreign students, but more broadly - to the selection of such texts that should help in modeling the speech consciousness of foreign communicants.

In his works, F. Bacevich gives a very clear definition of the term text (in the communicative aspect). He claims that the text is "a phenomenon of linguistic and non-linguistic reality - a complex phenomenon that, in addition to being involved in communication, helps to store and transmit information in space and time, records the life of individuals, is a product of a specific historical era, a form of cultural existence, a reflection of certain socio-cultural traditions" [1, p. 146]. The study of the text from the point of view of speech intellectualization is considered by L. Shevchenko, in the historical and stylistic aspect - by G. Shevchenko, in the triad of concepts "society-culture-language personality" - T. Radzievskaya, in the medialinvgistic context $-\mathrm{D}$. Sizonov etc.

A text that solves certain methodological problems is called educational (which is traditionally considered in linguomethodics as the main element in communicative learning). It is not only a means of mastering new language material, but also a means of mastering all types of speech activity. According to our observations, an educational text aimed at learning the language by foreigners must meet the following requirements:

$>$ readability;

$>$ professional orientation;

$>$ compliance with students' language and background knowledge;

$>$ informative content and compliance with students' interests.

The main task of a teacher of Ukrainian as a foreign language is to maximize the use of the material of the educational text for the development of grammatical and language skills and abilities of students, because it is necessary to encourage them to 
express and prepare for natural communication. First of all, the teacher should carefully analyze the text in terms of its potential opportunities for entering the situation of natural communication and the lexical and grammatical material presented in it, which is necessary for the design of a speech expression.

The text can include both morphological and syntactic, lexical-grammatical and stylistic constructions, as well as elements of monologue and dialogic speech. It should be noted that the style characteristics of the text play a key role in educational activities (for an indication of the style characteristics of texts, see the works of leading stylists S. Ermolenko, L. Shevchenko, L. Matsko etc.). Of course, all these functions cannot be presented together in one text, so it is important that the text corresponds to the purpose and objectives of training, that is, it must be appropriate and motivated in educational activities. The need for the text to correspond to the language phenomena being studied means that language learning begins on the basis of specially created texts. Gradually, it is necessary to move from educational to adapted, and then to original texts, but the requirement of text orientation to a certain language material remains all the time of the initial and main stages in educational activities. That is why it is possible to trace the sequence of presentation of texts to foreign students: adapted texts that form basic skills and unadapted texts of various genres that teach understanding by ear [3, p. 129].

We also consider it important to teach media literacy to foreign students. Thus, the flow of texts in the media that teachers can work with in the student audience is a representative of the mass consciousness of Ukrainians, and therefore they can become an object for foreign students to analyze Ukrainian realities (see research on positive / negative / neutral media contexts manipulated by Ukrainian media and ways to solve these problems by recipients [12]).

To learn Ukrainian as a foreign language, teachers often use country-specific texts. The selection of texts of this nature is carried out according to certain criteria, namely: 
$>$ authenticity (produced in the environment where the language is being studied);

$>$ country studies saturation (the amount of linguistic and Foreign Studies information in the text);

$>$ relevance (up-to-date and up-to-date informative content for the student);

$>$ typicality (systematic reproduction in typical communicative situations) [2].

Cultural texts play a significant role in the methodology of teaching Ukrainian as a foreign language, because the purpose of teaching foreign students is not only to learn the language, but also to study the Ukrainian reality, the opportunity to better understand the mentality and sociological aspect of the country whose language is being studied. It is for this purpose that texts and tasks for them have been developed, which will later be included in the educational and methodological development intended for foreigners studying the Ukrainian language.

The subject of the texts concerns the city of Kyiv and its main monuments of culture, architecture, places of recreation and leisure. Total number of created texts is 7 .

Tasks in stylistic linguoanalysis, grammar, and word formation are provided for each text. The latest tasks are creative, allowing you to comprehensively assess students and their knowledge of the language. Some of the tasks involve working with students' coherent speech, which also allows them to assess their level of proficiency in the Ukrainian language in various areas of public communication. At the beginning of each text, a dictionary is provided - a minimum of new words and phrases that take into account their semantics and evaluation in contexts.

The relevance of creating texts is called by the opportunity to study the Ukrainian language while getting acquainted with country studies texts and materials for them, because thematic blocks of local lore contribute to the acculturation of foreign students in the process of getting acquainted not only with the historical and geographical features of the country of residence and study, but also, equally, with 
the linguistic and cultural features of the spiritual and material culture created by the nation.

To analyze the created texts, it is necessary to consider their topics in more detail, and systematize the tasks developed for each text. As noted earlier, seven texts have been created, the subject of which helps to get acquainted in detail with the sights of the capital of Ukraine, namely:

$>$ The heart of our country. After reading this text, we can learn not only about the creation of the Ukrainian capital, but also get acquainted with the rich infrastructure of Kyiv.

$>$ From Yar to the main street of Kyiv. The theme of the second text is devoted to Khreshchatyk, or rather its creation and history from ancient times to the present.

$>$ Nature and technology. This text deals with Vladimirskaya Gorka and transport, which not only connects the two parts of the city, but is also an architectural monument-the funicular.

$>$ Andreevsky descent-Street-museum. On the topic of this text, it is already clear that it is dedicated to the street, each corner of which has its own rich history.

$>$ The oldest street in Kyiv. This text will reveal the history and highlights of Vladimirskaya Street.

$>$ The legendary Sofiyevskaya square. The text is dedicated to a square with a rich history, which is now the site of all cultural events.

$>$ A gem of architecture. The text will focus on the building of one of the best theaters of our time - the National Opera House [5; 6].

These texts are accompanied by visual materials in the form of drawings, and will help not only in learning the language, but also encourage the study of our culture and will become a guide for every foreigner in learning about our capital.

Each of these texts also helps in learning grammar, because they have their own grammatical features. For example, the text "heart of our country" uses different degrees of comparison, which 
helps a foreign student to easily assimilate them, and the text "Andreevsky descent - Street-museum" is full of possessive adjectives, which helps a foreigner to understand their education. Therefore, before reading the text, students should be introduced to new lexical units, grammatical and syntactic phenomena that occur in it. Then the text will help you understand and assimilate all the new material.

To improve the performance of language learning, texts need to be read several times. The purpose of the first reading of the text is for students to understand it. It is very effective to read the text simultaneously by the teacher (aloud) and students (to themselves), because this is how foreign students hear the correct pronunciation and expressive intonation. The next reading takes place in the next lesson, after careful familiarization with the text at home, which serves as an awareness of what is read when reading aloud in Turn [4, p. 159].

Tasks that accompany texts can be classified according to our observations, according to the stages of their implementation:

$>$ Tasks performed before reading the text.

$>$ Tasks that are performed while reading the text.

$>$ Tasks that are completed after reading the text.

Let's look at some possible examples of tasks that you should use when working with text.

Tasks performed before reading the text should teach the student to understand words, phrases, and individual positions in the text; they should remove difficulties associated with understanding the content of the text. Here are some examples of tasks that are performed before reading the text:

- Read and translate unfamiliar words and phrases.

- Write down and learn new words

$>$ Fill in the table (antonyms-synonyms).

$>$ Form nouns based on the given model.

$>$ Read words and phrases. Find antonyms.

To understand whether foreigners are aware of what they have read, the necessary tasks that they perform while reading, for example: "find a place in the text where it says about...", "Find the 
following words in the text ...", "Determine which part of speech these words belong to", "read the passage that you liked", "put the underlined words in the correct form", etc. performing tasks of this type teaches foreigners to navigate the text, gives them the opportunity to understand what they read.

After the text is read, the student proceeds to complete tasks. They consolidate the lexical and grammatical material, which includes the text, and prepare students for retelling based on special schemes, form and develop the student's skills of reproductive, reproductive and productive types of speech activity in accordance with the language program. The most common task is to answer questions about the text and retell it. Tasks for selecting verbs for nouns relative to the text are presented, and it is suggested to select the necessary words for the sentence, from the help provided, so that the meaning is not lost. These exercises will help to increase the vocabulary of a foreign student, as well as the ability to correctly form sentences and phrases. A productive task is one in which you need to write down the words in parentheses in the correct form this helps you learn and deftly use cases when communicating in the language you are learning. There may be significantly more tasks that are performed after reading the text than tasks from the previous two groups of our classification, for example:

Remove an extra word or phrase from each group of words.

$>$ Read the sentence. Write out only those that correspond to the subject of the text.

$>$ Enter the missing words using the text.

$>$ Write the components that form complex words.

$>$ Answer the question using the text information.

$>$ Read these statements. Identify them as right or wrong.

$>$ Get antonyms for the submitted terms.

$>$ Write down the keywords of the text

$>$ Read the text again and write down a short retelling of what you read.

$>$ Use the arrow to connect words by meaning. 
Insert the missing verbs.

Create a dialog on the topic of the text.

Make a story about your favorite place in Kiyv.

Form degrees of comparison from the submitted words.

Also, at this stage of working with text, you can offer students an exercise with game elements. For example, each student is given letters and pictures depicting new vocabulary to the text. The task is to collect words from the letters that will correspond to the pictures. This is a task aimed at quickly learning new words.

A teacher of Ukrainian as a foreign language can create different situations based on the content of the text, thus encouraging students to make monologue and dialogical statements. Speaking in the process of such work is dialogic and monologue unprepared or partially prepared speech. The conversation takes a lot of time and covers the entire content of the text. If presented correctly, all students participate in the conversation. In the process of speech activity of students, language material is mastered. At the same time, the teacher should monitor the correct use of new lexical units and grammatical phenomena in the speech of foreign students. Some of the questions on the content of the text can be prepared by students [8, p. 183].

In the process of teaching Ukrainian as a foreign language, it is necessary to carry out systematic work on the development of reading skills as an independent type of speech activity, because the text read and understood by students is a means of mastering other types of speech activity, for example, speaking and listening.

All three types of tasks are characterized by the fact that special attention is paid to the active development of vocabulary and grammatical structures that are relevant to the topics of each text.

We must not forget that each text must have three functions:

$>$ The text is an example of a functional and semantic type of speech (a way of presenting information).

$>$ Serves as a source of information for communication on a specific topic. 
$>$ The text is the basis for the interrelated study of four types of speech activity.

As a rule, the purpose of training always determines the choice of methods. For foreigners studying the Ukrainian language, constructive communication with Ukrainian speakers, official correspondence in the Ukrainian language, that is, professional activity, mainly gives motivation.

In this aspect, a creative approach to working with text is an effective solution to educational problems, which is based on the analysis of the ratio of speech, speech and thinking, thinking and communication. Below is the practical part of working with the text for learning Ukrainian as a foreign language.

So, the title of the text is "the oldest street in Kyiv"(Vladimirskaya Street)

Tasks performed before reading the text:

$>$ Use the title of the text to determine what will be discussed, and then read the text.

$>$ Translate unfamiliar words and phrases.

$>$ Make possible phrases with these nouns and adjectives. Tasks that are performed while reading the text:

$>$ Read the passage you liked.

$>$ Put the words underlined in the correct form.

Tasks that are completed after reading the text:

$>\quad$ Answer the questions.

$>$ Put words from the help instead of dots.

$>\quad$ Use the arrow to connect words by meaning.

$>\quad$ Match common root words to suggested nouns.

$>$ Transform your sentences according to the pattern without losing their meaning.

Form degrees of comparison with the submitted words and make phrases and sentences with them.

Make a sentence out of the suggested words.

Find masculine nouns and put them in the genitive singular form and divide them into two groups: the ending $-a,-x$ and the ending $-y,-\wp$. 
> Create a dialogue that is possible while walking along Vladimirskaya street. Use facts and architectural monuments from the text "the oldest street in Kyiv".

$>$ Listen to the national anthem of the city of Kyiv "How Not to love you, my Kyiv". Check out the main shrines of the city in pictures.

$>$ Write about your favorite place in Kyiv, using new words [6].

Based on all of the above, we consider that text analysis when learning Ukrainian as a foreign language helps not only to master the language, but also to understand the mentality of another people, to form cross-cultural competence. That is why the arsenal of a teacher of Ukrainian as a foreign language should be a variety of texts that correspond to cultural topics, as well as the interests and abilities of students. As a result of the study, it can be concluded that the educational text when learning Ukrainian as a foreign language is not only a means of teaching foreign students to read in Ukrainian, but also an excellent opportunity for the formation and development of their speaking, listening and writing skills. The use of texts on cultural topics makes it possible to show all the beauty of our country, instill in foreign students a respectful attitude and increase interest in the Ukrainian people and their achievements in various fields of culture, to the dramatic pages of its history, as well as to encourage students to travel and excursions, to active communication with the hospitable and friendly Ukrainian population, which will be another important stage in learning the Ukrainian language, because even more its beauty is revealed in communication.

\section{REFERENCES}

1. Bacevich, F.S. (2004). Fundamentals of communicative linguistics [Osnovy komunikatyvnoi' lingvistyky]. Kyiv: Akademiya publ., 344 p. [in Ukrainian].

2. Galka, Yu. (2020). Teaching Ukrainian as a foreign language in the linguistic and Foreign Studies aspect [Vykladannja ukrai'ns'koi' movy jak inozemnoi' u lingvokrai'noznavchomu aspekti]. URL: http://www.kmp.fl.kpi.ua/uk/node/45 [in Ukrainian]. 
3. Derba, S.M. (2018). Text as the main tool in the process of teaching Ukrainian as a foreign language [Tekst jak osnovnyj zasib u procesi navchannja ukrai'ns'koi' movy jak inozemnoi']. Scientific notes of the National University "Ostroh Academy": Series "Philology". Issue 1 (69), Part 1, 128-130. [in Ukrainian].

4. Dmitrieva, D.D. (2016). The role and functions of the teacher in the process of teaching Russian as a foreign language [Rol' y funkcyy prepodavatelja $\mathrm{v}$ processe obuchenyja russkomu jazuku kak ynostrannomu.]. Methods of teaching foreign languages: traditions and innovations: Collection of scientific papers based on the materials of international conferences. scientific and methodological conferenceswebinars (Kursk, April 12-15, 2016). Kursk: KSMU publishing House, 2016, 158-163 [in Russian].

5. Zlotnik-Shagina, O.O. (2017). Educational and methodical developments in the Ukrainian language for foreign students "Excursions in Kyiv" [Navchal'no-metodychni rozrobky z ukrai'ns'koi' movy dlja studentivinozemciv "Ekskursii' v Kyjevi"]. Kyiv: Logos publ., 35 p. [in Ukrainian].

6. Zlotnik-Shagina, O.O. (2020). Educational and methodical developments in the Ukrainian language for foreign students "Excursions in Kyiv" [Navchal'no-metodychni rozrobky z ukrai'ns'koi' movy dlja studentivinozemciv "Ekskursii' v Kyjevi"] (part two). Kyiv: Logos publ., 35 p. [in Ukrainian].

7. Turkevich, A. (2008). Eatures of using cultural texts in the process of teaching Ukrainian as a foreign language [Osoblyvosti vykorystannja kul'turologichnyh tekstiv u procesi navchannja ukrai'ns'koi' movy jak inozemnoi'.]. Theory and practice of teaching Ukrainian as a foreign language, 3, 277-280. [in Ukrainian].

8. Shvets, G.D. (2014). Academic discipline "Linguostylistic analysis of text in the course of teaching Ukrainian as a foreign language" and its place in the system of professional training of a teacher-philologist [Navchal'na dyscyplina "Lingvostylistychnyj analiz tekstu v kursi vykladannja ukrai'ns'koi' movy jak inozemnoi'" ta i'i' misce v systemi fahovoi' pidgotovky vykladacha-filologa]. Theory and practice of teaching Ukrainian as a foreign language, 10, 179-186 [in Ukrainian].

9. Sharafutdinov, R.R. (2008). Linguistic regional studies and its role in foreign language education [Lingvostranovedenie i ego rol' $\mathrm{v}$ inojazychnom obrazovanii]. Bulletin of the Kazan technological University, 5, 231-236. [in Russian]. 
10. Dirk, G. \& Cuyckens, H. (ed.) (2007). The Oxford handbook of Cognitive Linguistics. Oxford: Oxford University Press, 1334 p. [in English].

11. Sametova, F., Kurmanali Chakyroglu, A., Smanova, B., Sarymbetova, A., Seidikenova, A. (2019). Representation Of The Concept Of Time In The Linguistic Consciousness. OPCIÓN, 35, Núm. 88, 27-52 [in English].

12. Syzonov, D. (2017). Psycholinguistic bases of media literacy: considering the issue of media texts interpretation. Science and education, 7, 82-88. DOI: https://doi.org/10.24195/2414-4665-2017-7-13 [in English].

13. Takahashi, K. \& Piller, I. (2011). Linguistic diversity and social inclusion. International Journal of Bilingual Education and Bilingualism, 14(4), 371-381. DOI: 10.1080/13670050.2011.573062 [in English]. 